\title{
PERSONALISTIČKI SKLOP INTELIGENCIJE I USPJEŠNO UČENJE
}

\section{Sažetak}

S obzirom da je učenje centralni pojam,kad je riječ o odgoju i obrazovanju, nužno mu je posvetiti punu pažnju. Dužnost škole je da osposobljava učenike za samostalno učenje $i$ da kod njih razvija kompentencije koje im omogućuju da budu aktivni sudionici nastavnog procesa.Uvažavajući individualne sposobnosti svakog učenika odgajatelji će stvarati takvu socio-emocionalnu klimu u razredu koja će osigurati ravnopravan tretman $i$ uspješno savladavanje programskih sadržajasvih učenika u skladu s njihovim mogućnostima i sposobnostima. Odgovornost odgajatelja je velika, teška, ali $i$ plemenita i lijepa. Zar ima nešto ljep̌se od susreta odgajatelja i učenika?

Aktuelno pitanje u današnjoj školi je uključivanje djece s teškoćama u razvoju $u$ redovna odjeljenja. To je jako važan momenat $u$ sistemu odgoja $i$ obrazovanja jer se radi o osobama koje imaju posebne potrebe s aspekta teškoća u razvoju i neminovno zahtijevaju poseban tretman kako bi ostvarili rezultate $u$ skladu sa svojim mogućnostima $i$ sposobnostma. Zato je veoma znaćajno poznavati personalistički sklop inteligencije svakog učenika. Ta spoznaja nas usmjerava kako uspješno raditi, kako uskladivati naše zahtjeve, koje metode $i$ postupke koristiti za ostvarivanje optimalnih rezultata s njma.

Uspješno učenje ostvarit će oni odgajatelji koji u svome radu budu ispoljavali ljubav, interes $i$ stručnost za posao koji obavljaju. Medutim, to je samo jedna strana uspješnog odgojno-obrazovnog rada. Akteri u nastavnom procesu (ili bi bar trebali biti) su $i$ učenici od koji zavisi uspjeh u učenju. Njihov interes, motiviranost za učenje uz adekvatno korištenje vlastitih potencijala osigurat će da učenje bude uspješno.

Ključne riječi: pesonalistički sklop, inteligenciaj, učenje, ekstravertnost, introvertnost, neuroticizam, socijalna zrelost, emocionalna zrelost, faktori, G-faktor, intrapersonalna osjetjivost, interpersonalna osjetlivost, artificijelnalumjetnalkompjutorska inteligencija, intrinzična motivacija, ekstrinzična motivacija.

${ }^{1}$ Islamski pedagoški fakultet u Bihaću. 


\section{UVOD}

Osnovna zadaća škole kao odgojno-obrazovne ustanove je sistematski rad na odgoju i obrazovanju mladih generacija. Bez sumnje, uspjeh svake osobe u neposrednoj je zavisnosti od učenja koje predstavlja jednu od najvažnijih čovjekovih aktivnosti. Realni izgledi za uspješno učenje i ostvarivanje dobrih rezultata u školi, pored učenja, su i saznanja o zakonitostima psihofizičkog razvoja ličnosti, stepenu kognitivnih, emocionalnih i motivacionih razvojnih stupnjeva te o dostignutom nivou odgojno-obrazovne tehnologije.

Na uspjeh učenika u školskom učenju djeluju, pored općih sposobnosti i niz faktora, osobina ili crta ličnosti. Nije bez razloga programski zahtjev da se odgojno-obrazovni rad mora usklađivati s dječijim razvojnim stupnjevima, njihovom maturacijom i ostalim faktorima razvoja, što sve značajno doprinosi uspješnoj individualizaciji nastavnog procesa. Takav odnos u punoj mjeri osigurava uvažavanje individualnih sposobnosti što podrazumijeva primjenu izdiferenciranih kriterija. Stoga će učenici u nekim oblastima, nastavnim predmetima postizati bolje, a u nekim slabije rezultate. Neopravdano je, ali i nehumano, zaustavljati učenike u njihovom napredovanju zbog eventualnog i relativnog neuspjeha u nekoj oblasti što bi dovelo do njihovog zaustavljanja u daljem školovanju i napredovanju.

Intelektualne sposobnosti čine osnovu za uspješno napredovanje $u$ školskom učenju posebno kada su praćene sa povoljnim osobinama ličnosti. Tu, prije svega, mislimo na inteligenciju jedne ličnosti koja je u osnovi jedinstvena i uvijek je nerazdvojno spojena sa cjelokupnom ličnošću.

Uspjeh u školi obuhvata sve bitne komponente nastavnog rada među kojima treba posebno istaći stjecanje znanja, vještina i navika, razvijanje psihičkih i fizičkih sposobnosti, razvijanje pravilnog pogleda na svijet te razvijanje i učvršćivanje kompentencija svakog učenika ponaosob.

Dakle, uspjeh učenika u školskom učenju nije rezultat isključivo njihove inteligencije, i zato G. Olport, američki psiholog, ističe: „Ono što nalazimo kod realnih ljudi, to je personalitički sklop inteligencije koja je tesno isprepletena interesima, crtama i pogledom na život. Korisno je ponekad znati koliki je iznos faktora „G““ (IQ) ili koliki su 
bodovi za naročite veštine (npr. verbalnu,mehaničku) ili imati profil „primarnih sposobnosti“ (jezik, broj, prostorno mišljenje, mehanički principi, spretnost, percepcija, učenje, rezonovanje). ${ }^{2}$

Prema Veksleru, inteligencija se mora razmatrati kao manifestacija ličnosti u cjelini. Veksler ističe da su s inteligencijom tijesno povezane osobine kao što su motivi postignuća, interesi, istrajnost, osobine temperamenta, kapacitet prilagođavanja i naziva ih personalnim komponentama inteligencije.

R. Kvaščev, također, ističe da je opravdano ukazivati na postojanje personalnih komponenata inteligencije. Prisutna je, ističe Kvaščev, pozitivna povezanost određenih osobina ličnosti i inteligencije. Utvrđena je visoka povezanost inteligencije i motivacionih osobina, inteligencije $\mathrm{i}$ tipa temperamenta te sposobnosti i osobina karaktera $\mathrm{i}$ inteligencije. Sve to ukazuje na potrebu poznavanja općih sposobnosti učenika, crta ličnosti i grupnih faktora kako iz praktičnih, tako i iz teorijskih razloga. Jer, školski uspjeh je povezan sa ličnošću učenika, sa njegovom inteligencijom, njegovim interesima, marljivošću, motiviranošću i niz drugih crta ličnosti što sve zajedno doprinosi postignućima učenika u učenju.

\section{Postignuća i inteligencija}

Nužno je razlikovati postignuća i inteligenciju. Dok postignuća predstavljaju iskustveno stečena znanja i vještine usvojene kroz sadržaje nastavnih predmeta, inteligencija predstavlja spoznajnu osnovu za postignuća kao što je sposobnost za učenje.

Međutim, uspjeh u školskom učenju u znatnoj mjeri zavisi i od sposobnosti, potencijala i zalaganja nastavnika, od brige i pomoći roditelja, od nastavne tehnologije.

Prema Enciklopedijskom rječniku pedagogije uspjeh u nastavi označava se ,...nastavnom djelatnošću postignuti nivo realizacije materijalnih, formalnih i odgojnih zadataka nastave, specificiranih nastavnim programom, tj. stupanj u kojem su učenici trajno usvojili nastavnim programom propisana znanja, vještine i navike, razvili svoje

${ }^{2}$ Olport, G., Sklop i razvoj ličnosti, Kultura, Beograd, 1969. 
psihofizičke sposobnosti i formirali moralno spoznavanje, htijenje i djelovanje. “3

Danas je vrlo aktuelno pitanje uspjeha djece s teškoćama u razvoju i načina rada s njima. Prevaziđeno je mišljenje da djeca koja imaju teškoće u razvoju pa time i teškoće u učenju treba izdvajati u specijalne škole i odjeljenja. Ova djeca žive i živjet će u normalnim sredinama. Potpuno opravdano se djeca s teškoćama u razvoju uključuju u redovna odjeljenja i kroz proces inkluzije pripremaju se za život u okruženju. Rad sa ovom djecom, inkluzivna nastava, zahtijeva poseban tretman i djece i nastavnika. Uvažavanje individualnih razlika uzrokovanih razlikama u sposobnostima i mogućnostima učenika jedan je od osnovnih preduvjeta ispravnog tretmana ove djece. Nastavnici su u radu s ovom djecom izloženi povećanom naporu jer organizacijom nastave moraju osigurati adekvatan tretman ove djece, ali su stavljeni $u$ poziciju da ne smiju zanemariti uobičajene i posebne potrebe ostalih učenika, a posebno darovitih učenika, jer i takvim učenicima treba pružiti više podrške, pažnje i znanja.

Pojava neuspjeha u školskom učenju ima dalekosežne psihološke implikacije. Neuspjeh kod učenika izaziva različite psihološke posljedice koje dovode do poremećaja u razvoju ličnosti učenika. Posebno je štetno ako dođe do gubitka povjerenja u vlastite mogućnosti i stvaranje uvjerenja o manjoj vrijednosti u odnosu na druge učenike. Kompetentni nastavnici mogu pomoći u prevazilaženju poteškoća i vraćanju povjerenja u vlastite sposobnosti, što je posebno značajno kod vulnerabilnih učenika. Pravovremene intervencije su od neprocjenjive vrijednosti za uspostavljanje pozitivne ravnoteže i sprečavanje pojava povlačenja u sebe, odbijanje učestvovanja u životu i radu odjeljenjskog kolektiva, pojave pasivnosti, nepovjerenja u okolinu pa sve do pojave loše slike o sebi pa čak i do pojave agresivnih oblika ponašanja.

Neuspjeh u školskom učenju proizvodi i socijalne implikacije kao otuđenje od škole, nemogućnost afirmiranja u socijalno prihvatljivim oblicima ponašanja kao učenje, sudjelovanje u radu razrednog kolektiva, angažovanost u slobodnim aktivnostima i umjesto ovih

3 Enciklopedijski rječnik pedagogije, Uspjeh u nastavi, Matica hrvatska, Zagreb, 1963. str. 1076. 
pribjegavaju neprihvatljivim oblicima ponašanja kao skitnja, agresivnost, delinkvencija i slično.

Na veliki značaj učenja i aktivnosti subjekata pri učenju ukazao je i R. Kvaščev ističući da učenje prožima cjelokupnu aktivnost ličnosti. Kvaščev učenje definiše „,... kao svaka relativno trajna i progresivna promena ličnosti, odnosno, njenog ponašanja koje nastaje kao rezultat ranije aktivnosti. Najšire shvaćeno, učenje je menjanje ličnosti. Učenje je pretežno uslovljeno delatnošću same ličnosti.““

M. Čudina i J. Obradović učenje definišu kao „Promjene u ponašanju pojedinca koje nastaju na osnovu izbora i sadržavanja onih oblika ponašanja koje $u$ toku individualnog iskustva imaju prilagodbenu vrijednost za pojedinca. “5

I. Furlan učenje definiše na slijedeći način: „Učenje možemo definirati kao usvajanje novih, dubljih i tačnijih oblika odražavanja vanjskog svijeta u našoj psihici i kao stjecanje i dalje razvijanje novih, pravilnijih i efikasnijih oblika reagovanja na zbivanja i pojave u tom svijetu. ${ }^{* 6} \mathrm{~B}$. Stevanović pojam učenja određuje kao „Učenje je menjanje jedinke. Ono je uslovljeno njenom delatnošću koja je izazvana njenim potrebama i određenim uticajima sredine“"7

N. Rot ističe da pod učenjem treba podrazumijevati relativno trajne promjene ponašanja na osnovu iskustva.

Iz ovih i drugih definicija učenja jasno se vidi da učenje dovodi do trajnih i progresivnih promjena ličnosti, da je učenje pokretačka snaga razvoja psihomotorike, da je uslovljeno djelatnošću same ličnosti, da učenje dovodi do socijalizacije čovjeka, postajanja čovjeka čovjekom itd. R. Kvaščev opravdano ističe značaj učenja u neprestalnom mijenjanju ličnosti i kaže: „Deca se uče da budu društvena, kooperativna, učtiva, vredna i požrtvovana, ali se uče da budu i asocijalna, agresivna, tvrdoglava, lenja itd. Učenje omogućava čoveku

\footnotetext{
${ }^{4}$ Kvaščev, R., Primena teorija učenja na oblast nastave i vaspitanja, ZZUDŽB SR Srbije, Beograd, 1974.

${ }^{5}$ Čudinaa, M, Obradović, J., Psihologija, Panorama, Zagreb, 1967.

${ }^{6}$ Furlan, I., Osnove procesa učenja, Školska knjiga, Zagreb, 1969.

7 Stevanović, B., Pedagoška psihologija, Zavod za izdavanje udžbenika SR Srbije, Beograd, 1964, str 55.
} 
ne samo da se prilagođava sredini u kojoj živi, već se učenjem osposobljava da menja tu sredinu prema svojim potrebama. ${ }^{\text {“8 }}$

I najnovija psihološka i pedagoška istraživanja orijentirana su na otkrivanje onih oblika nastave koji će osigurati najbolje učenje. Naglašava se da neusklađenost utisaka što ih primamo smanjujenaše mogućnosti učenja. Zato je važno da se za vrijeme učenja isključe ili eliminišu nepotrebni ili irelevantni utisci, dakle, distraktori ili ometači koncentracije i pažnje. Bitno je da se osigura da pri učenju sudjeluju i audio i video komponenta, jer je utvrđeno da su uspješnija izlaganja koja su popraćena i audio i video komponentom. To, kako kaže I. Furlan ,, i naučna psihološka istraživanja i praktična pedagoška iskustva govore da su za školsko učenje bitne samo dvije komponente: audiokomponenta i videokomponenta. “9

Sve aktivnosti koje su u skladu s predmetom učenja nazivaju se relevantnim, za razliku od ostalih koje su irelevantne, smatra I. Furlan. Furlan naročito ističe značaj nivoa aktivnosti u uspješnom učenju. Pasivno slušanje je najniži nivo aktivnosti u učenju, smatra I. Furlan, iako ono dominira u većini škola, što je sigurno jedan od indikatora slabog znanja i slabog uspjeha. Viši nivo aktivnosti predstavlja samostalno čitanje nekog teksta, a još viši, bilježenje u vezi s tekstom ili predavanjem. Samostalno prepričavanje ili reprodukovanje pročitanog predstavlja slijedeću višu stepenicu aktivnosti prilikom učenja, a diskusija, suprotstavljanje mišljenja, još višu. Najviši nivo aktivnosti predstavlja rješavanje problema. Nažalost, u većini naših škola aktivnost učenika ostaje na nivou pasivnog slušanja. Uz audiokomponentu i videokomponentu potrebno je kontinuirano i intenzivno aktivirati učenike $\mathrm{i}$ osigurati potkrepljenje aktivnosti (stalne povratne informacije i podsticaji).

\footnotetext{
${ }^{8}$ Kvaščev, R., Razvijanje kritičkog mišljenja kod učenika, ZZUDŽ SR Srbije, Beograd, 1967., str. 2.

${ }^{9}$ Furlan, I., Osnove procesa učenja (Priručnik za nastavnike i student nastavničkih škola), Školskaknjiga,Zagreb, 1969. str. 5.
} 


\section{Inteligencija kao središnjica personalističkog sklopa i uspjeh u učenju}

Dokazano je da se ljudi razlikuju po svojim intelektualnim sposobnostima. Uspjeh u različitim poslovima pa i u učenju zavisi od stepena razvijenosti većeg broja intelektualnih sposobnosti kao sastavnog dijela inteligencije. Psiholozi se razlikuju u mišljenju da li je inteligencija jedna jedinstvena sposobnost ili se sastoji od određenog broja različitih posebnih sposobnosti. Tako Z. Bujas smatra da ono što daje jedinstveno obilježje inteligenciji, iako ona nije jedinstvena sposobnost, jeste jedinstveno polje u kome ona dolazi do izražaja. Ne postoje zadaci kod kojih se ne nailazi na kombinaciju više faktora pri njihovom rješavanju. Činjenica je da inteligentne osobe imaju visoku sposobnost učenja, da mnogo lakše rješavaju različite probleme, da imaju veće samopoštovanje prema sebi, da su socijalno osjetljivije, a od manje inteligentnih ralikuju se i po tome što se mnogo češće nalaze u problemskim situacijama tj. što često vide probleme i tamo gdje ih drugi ne vide.

N. Rot ukazuje na povezanost učenja, inteligencije i kritičkog mišljenja. „Da postoji kvalitativno različit uticaj inteligencije na uverenost kod sudova različite psihološke strukture, a što bismo mogli objasniti razlikom između inteligentnijih i manje inteligentnih u poverenju koje oni imaju u podatke na kojima počiva sud. U sudove koji počivaju na logičkoj evidentnosti i na neposredno percipiranim podacima, inteligentniji imaju veće poverenje nego manje inteligentni, a u sudove koji počivaju na afektivnom odnosu, subjektivnom iskustvu i naučnom autoritetu imaju manje poverenja." ${ }^{10}$

R. Kvaščev ističe „,...da razvijenost kritičkog mišljenja utiče na razvoj ličnosti pomoću:

- kritičke identifikacije u različitim oblastima;

- kritičkog verifikovanja svih vrednosti pre njihovog prihvatanja i usvajanja;

- razvijanju kritičnosti u odabiranju ideala i uzora;

${ }^{10}$ Rot, N., Psihologija ličnosti, Zavod za izdavanje udžbenika i nastavna sredstva, Beograd, 1972. 
- kritičkog preispitivanja vođa grupa, timova itd;

- kritike određenih vrednosti u socijalnoj interakciji i komunikaciji;

- kritičkog prosuđivanja i procenjivanja ponašanja ljudi koji intenziviše razvoj tzv. socijalne inteligencije ličnosti.“"11

Prema Spirmanu, u strukturi inteligencije treba nužno voditi računa o dva faktora, opštem i specifičnom koji se javljaju u svakoj ljudskoj sposobnosti. Opća sposobnost ili „G“ faktor, ima izvjesnu ulogu u svakoj ljudskoj aktivnosti, ali u mnogim djelatnostima uspjeh zavisi od specifičnih sposobnosti. Gotova svaka aktivnost uključuje bar jednu specijalnu spsobnost, ali sve ili gotovo sve uključuju opće sposobnosti. $^{12}$

Prema L. Terstonu, inteligenciju čine sedam faktora zajedno sa generalnim faktorom. To su:

- W- faktor ili sposobnost rječitosti. Ovaj faktor manifestuje se u sposobnosti lakog nalaženja riječi i bogatstvu rječnika;

- V- faktor manifestuje se u sposobnosti za razumijevanje verbalno formulisanog sadržaja;

- N-faktor, ili numerički faktor, kojeg karakteriše sposobnost uspješnog operisanja brojevima;

- S-faktor, ili spacijalni faktor. Ovaj faktor manifestuje se u sposobnosti predstavljanja i zamišljanja prostornih odnosa;

- M-faktor, ili faktor memorisanja, sposobnost pamćenja, prije svega, materijala bez smisla, logičkog materijala koji se mora mehanički pamtiti;

- P-faktor, ili faktor percipiranja, koji se ogleda u sposobnosti uočavanja malih razlika u dražima posredstvom vida;

- R-faktor, ili faktor rezonovanja. Ovaj faktor manifestuje se u sposobnosti nalaženja općih principa, u sposobnosti rješavanja

\footnotetext{
11 Kvaščev, R., Razvijanje kritičkog mišljenja kod učenika, Zavod za izdavanje udžbenika, Beograd,1967. str. 25.

${ }^{12}$ U: Rot, N., Psihologija ličnosti, Zavod za izdavanje udžbenika, Beograd, 1971, str. 66.
} 
problema. Smatra se da ovaj faktor ima najvažniju ulogu pri svim tzv. intelektualnim operacijama, dakle, pri aktivnostima koje zahtijevaju razvijenu inteligenciju. " 13

Američkipsiholog J.P. Gilford intelektualne sposobnosti dijeli na pet glavnih sposobnosti ili faktora i to: sposobnost pamćenja, sposobnost kognitivnog mišljenja, sposobnost konvergentnog mišljenja, sposobnost divergentnog mišljenja te sposobnost evaluativnog mišljenja, a uspjeh zavisi od sviju njih. ${ }^{14}$

R. Katel, također američki psiholog i veliki zagovornik faktorske analize ličnosti smatra da grupu primarnih sposobnosti čine: fluidna inteligencija, kristalizovana inteligencija, snaga vizualizacije, opća fluentnost i kognitivna brzina. Prema Katelu, fluidna inteligencija čini osnovu velikog broja intelektualnih aktivnosti. Ona je rezultat naslijeđa i u visokoj je korelaciji sa brzinom učenja u novim oblastima. Kristalizovana inteligencija, pored nasljedne osnove povećava se sa iskustvom ličnosti i obrazovanjem. Svoj maksimum dostiže poslije 20. godine i ne opada sa starošću. Čine je sposobnosti kao verbalno shvatanje, iskustvena evaluacija, sposobnost formalnog tj. silogističkog rezonovanja, sposobnost izvođenja novih semantičkih relacija, numerička sposobnost i originalnost. Fluentnost se ispoljava kroz proizvođenje velikog broja ideja, a faktor vizualizacije obuhvaća perceptualnu brzinu i vizualizaciju. ${ }^{15}$

Prema H. Gardneru, američkom psihologu, postoji sedam vrsta inteligencije, a svaka od njih ima svoju neurološku osnovicu $u$ različitim dijelovima mozga. To su: jezička sposobnost, logičkomatematička inteligencija, spacijalne sposobnosti, muzičke sposobnosti, tjelesno-kinestetske sposobnosti, intrapersonalne vještine ili intrapersonalna osjetljivost-osjetljivost za vlastite osjećaje i

\footnotetext{
${ }^{13}$ U: Rot, N., Psihologija ličnosti, Zavod za izdavanje udžbenika, Beograd, 1971 .str. 68.

${ }^{14}$ U: Rot, N., Opšta psihologija, Zavod za udžbenike i nastavna sredstva Srbije, Beograd, 1972, str. 165.

15 U: Rot, N., Psihologija ličnosti, Zavod za izdavanje udžbenika, Beograd, 1971, str.44.
} 
interpersonalne vještine ili interpersonalna osjetljivost-osjetljivost za osjećanje drugih ljudi. ${ }^{16}$

Aktuelno je pitanje korištenja artificijelne ili umjetne inteligencije koja predstavlja kompjutorsku kopiju ljudskog intelektualnog funkcioniranja. Od vizionarskih predviđanja da će strojevi s umjetnom inteligencijom moći razumjeti govor, donositi odluke, pisati knjige, dešifrirati nečitak rukopis, pretraživati pamćenje u potrazi za relevantnim informacijama, danas postaje realnost. Računari kojima danas raspolažemo mogu uspješno kodirati i pohranjivati informacije, rješavati vrlo složene probleme i donositi odluke. Zahvaljujući artificijelnoj inteligenciji, uz precizne upute i adekvatne formule, moderna računala danas mogu obaviti brojne složene intelektualne funkcije. U nekim složenim intelektualnim radnjama umjetna inteligencija nadmašuje ljudsku, prirodnu inteligenciju. Međutim, i najsavremenija računala ne raspolažu uvidom, intuicijom i kreativnošću koje su svojstvene samo čovjeku. Zahvaljujući ljudskoj inteligenciji čovjek planira, predviđa, emocionalno doživljava uspjeh i neuspjeh, nadahnjuje se rezultatima, razvija socijalnu osjetljivost, voli. Sve to ne može računar bez obzira na stupanj razvijenosti artificijelne inteligencije. Ali ujedinjeni u zajedničkom djelovanju uspjeh i rezultati su bez ograničenja.

„Čulnim opažanjem, mjerenjem i izračunavanjem (eksperimentom) koje predstavlja temelj svake konvencionalne nauke; znanja stečena posredstvom čula zovu se još iskustvena ili stečena znanja. „Aristotel kaže, da se život manifestira: hranjenjem, rastom (kretanjem), percipiranjem i mišljenjem. Dosljedno tome i biljke žive, i moć njihove duše je samo u hranjenju, tj. one sprovode samo vegetativni život. Duša životinje, pored sposobnosti hranjenja, ima i osjetilni život, a čovječija duša, pored vegetativnog i osjetilnog života, ima i razumsku moć, i razum je ono, čime duša razmišlja i shvaća." ${ }^{17}$

Konačni proces spoznaje vrši se u umu, koji je za Aristotela, kao i za Platona, samo dio duše.

\footnotetext{
${ }^{16}$ U: Rathus, S. A., Temelji psihologije, Naklada Slap, Jastrebarsko, 2003, str.261.

17 Makić, A., Komparacija odgoja $i$ obrazovanja $u$ islamskoj $i$ konvencionalnoj pedagogiji (magistarski rad), Islamski pedagoški fakultet, Bihać, 2015., str. 97.
} 
„Naučno je dokazano da i čula varaju-prividno prelamanje štapa u vodi. Prema tome, i znanje do kojeg dolazimo čulima, odnosno iskustvom, nije potpuno sigurno ili apsolutno. Sva su ljudska znanja relativna. Ljudi ne posjeduju izvore apsolutnih, neprikosnovenih znanja, jer se u njihovim izvorima uvijek nađe neki nedostatak ili manjkavost kao odraz atributa ljudske manjkavosti i nesavršenosti. Božijim otkrovenjem činjenica, uputstava i smjernica putem Objave preko Vjerovjesnika s.a.v.s.. Ovo znanje zove se Objavljeno znanje. Moramo istaći da iskustveno znanje u sferi pojavnog, fizičkog svijeta gdje iskustvo dolazi do izražaja može čovjeku ponuditi pouzdano znanje u pojedinim oblastima. No, međutim, kada su u pitanju neke vaniskustvene, metafizičke oblasti, iskustveno znanje je ograničeno. $\mathrm{Na}$ ovu ograničenost ljudskog uma ukazuje Uzvišeni Allah: „A vama se dalo samo malo znanja."18

Čovjek u ovoj oblasti može samo lutati ako se misli osloniti isključivo na svoje znanje stečeno osjetilima. Čak je i Aristotel to potvrdio, smatrajući: “Osjetila pružaju samo osjete o vanjskim predmetima, koje skuplja zajednički organ (u opažaje), i taj opažajni materijal svakog čovjeka nije ništa drugo nego njegova ispisana ploča (pasivni um), a to dalje obrađuje aktivni um, koji je prema Aristotelu - božanskog porijekla, i ima svoju preegzistenciju. ‘19

„Da bi u sferi pojmova došao do pravog znanja, čovjeku je nužan nadljudski, božanski izvor. Taj izvor je Božija objava ili otkrovenje (vahj). Ovom vrstom znanja bili su obradovani samo rijetki pojedinci, Allahovi odabranici, ali uz obavezu da prenesu to saznanje. Posljednju i kompletno očuvanu verziju tog saznanja zaključuje Muhamed, s.a.v.s., koji je čovječanstvu dostavio posljednju Božiju uputu, poruku, Kur'an - skoncentrirano znanje istina Njegovog izvora koje su dužni prihvatiti svi ljudi." ${ }^{20}$

Pored spomenuta dva puta spoznaje postoji još i znanje koje bismo mogli nazvati urođenim znanjem, jer je čovjeku dato nezavisno od

\footnotetext{
${ }^{18}$ Isto, str. 98.

${ }^{19}$ Isto, str. 98 .

${ }^{20}$ Isto, str. 98.
} 
spoljnih utjecaja-apriori. Ona se zovu još i nužna znanja: znati hodati, jesti i slično.

„Uvaženi šejh Yusuf el-Karadawi u svojoj knjizi „Poslanik, s.a.v.s., i nauka" ističući vrijednost nauke iznosi i argumentuje čitav niz tvrdnji:

- nauka je dokaz vjere,

- znanje je vodič u poslu,

- znanje je preduvjet valjanosti djela,

- ibadet koji nije popraćen znanjem nije ni ispravan,

- bez znanja nisu ispravni ni međuljudski odnosi,

- znanje je preduvjet za postavljanje na rukovodeće pozicije,

- nauka objašnjava kategorije djela i njihove prioritete,

- novotarije u vjeri rezultat su pomanjkanja znanja,

- prednost nauke nad ibadetom,

- prednost nauke nad džihadom,

- nauka je od koristi kad je riječ o ovome svijetu,

- bavljenje naukom najbolje je dobrovoljno djelo

- nestajanje znanja pokazatelj je propadanja ovoga svijeta.

Da bi se pojedinac ostvario kao pojedinac, a onda i kao član porodice i društva, on to može samo ako se u potpunosti preda i pokori Allahovoj volji i svoj život uskladi sa univerzalnim islamskim vrijednostima. Ove vrijednosti derivirane su iz samih izvora islama, časnog Kur,ana i iz života Božijeg poslanika, koji je bio utjelovitelj islama riječju, mišlju i djelom. Sažet pregled osnovnih vrijednosti mogao bi se dati u slijedećem:

Biti moralan u užem i širem značenju, u svakoj situaciji i na svakom mjestu (npr. čuvati svoj jezik od lažnog govora, prenošenja tuđih riječi, lažnog svjedočenja, krivog zaklinjanja, verbalnog uznemiravanja i ezijećenja, psovke i slično. Zatim, čuvati svoj spolni organ od svih zabranjenih vidova spolnog odnosa, kao i sve druge organe koji mogu dovesti u zabranjeni odnos. Eliminisati: varanje bilo koje vrste, 
pohlepu, mržnju, zavidnost ali i samodopadljivost, oholost, osionost i slično).

- Biti pravedan prema sebi i drugima, (npr. voditi računa da ne opterećujemo sebe ni druge poslovima ili drugim stvarima koje su izvan naših mogućnosti. Besprijekorna ravnopravnost i pravda prema djeci, ženama i eventualno radnicima koji za nas rade. „Allah naređuje da se svačije pravo poštuje“ 384 „Pravedni budite, to je najbliže čestitosti.“21

\section{Interpretacija rezultata istraživanja}

Opravdano se može postaviti pitanje zašto nas interesiraju rezultati koje postižu učenici u današnjim osnovnim školama. Svakodnevno čujemo komentare, posebno onih osoba koje su duže vezane za sistem odgoja i obrazovanja, da su sadašnji učenici s manjim radnim elanom, da manje vremena provode u učenju, da su suviše vezani za kompjutore, mobitele, televiziju i sumnjive televizijske emisije, da se malo bave knjigom i učenjem. A, ipak ostvaruju, u cjelini, visoke rezultate. Šta je stvarna istina i realnost? Prate li rezultate ostvarene na kraju prvog polugodišta školske 2015/16. godine adekvatne aktivnosti i zalaganja učenika? Samo djelimično možemo odgovoriti na postavljena pitanja. Djelimično, jer raspolažemo statistički nereprezentativnim podacima o uspjehu dijela učenika i odjeljenja iz jedne osnovne škole. Osim toga, nismo bili u mogućnosti provesti detaljnije istraživanje na terenu kako bismo dobili validne i relijabilne podatke pa su naši zaključci površni. Zbog ograničavajućih razloga nije bilo moguće primijeniti psihološke testove u odjeljenjima čije smo podatke o općem uspjehu koristili iz Izvještaja škole, a u odjeljenjima s kojima vršimo poređenje je učinjeno ,što također upućuje na manjkavost. Zato se unaprijed ograđujemo i ističemo da su nam za oko zapeli komparativni pokazatelji uspjeha učenika približnog stvarnog uzrasta i razreda kojeg su pohađali. Uzrast se razlikuje utoliko što se sada radi o devetogodišnjem osnovnom odgoju i obrazovanju pa se, ustvari razredi razlikuju, osmi, odnosno deveti.

Za istraživanje postavljenog problema odabran je uzorak od 6 odjeljenja sa ukupno 171 učenikom osmog razreda (78 dječaka i 93 djevojčice)

21 Makić, A, Komparacija odgoja i obrazovanja u islamskoj $i$ kovencionalnoj pedagogiji (Magistarski rad), Islamski pedagoški fakultet, Bihać, 2015, str. 94-97. 
dvije gradske osnovne škole $\mathrm{s}$ područja tadašnje općine Bihać. Distribucija učenika po uspjehu na kraju I polugodišta je slijedeća:

- odličnih - 23 ispitanika, (13\%),

- vrlo dobrih - 28 ispitanika, (16\%),

- dobrih - 55 ispitanika, (32\%),

- dovoljnih - 6 ispitanika, (3,5\%),

- nedovoljnih - 59 ispitanika, (35\%).

Vidljivo je da je visok procenat učenika koji nisu ostvarili pozitivan uspjeh. Izvjesno opravdanje može se tražiti u tome što se radi o rezultatima na kraju I polugodišta, pa se očekuje da će rezultati biti znatno bolji na kraju školske godine. Ali, opravdano se postavlja pitanje zašto je to tako i šta je stvarna razina znanja. Koji su to faktori koji uslovljavaju takav uspjeh na polugodištu, odnosno na kraju školske godine? Kada su nastavnici realniji u ocjenjivanju i u kojoj mjeri takva realnost utječe na osposobljavanje učenika za učenje.

Moramo napomenuti da se navedeni rezultati odnose na distribuciju uspjeha učenika VIII razreda na kraju prvog polugodišta školske 1976/77. godine. Dakle, prije 39 godina. U istim školama, ali u IX razredu u školskoj 2015/2016. godini ostvareni su slijedeći rezultati:

- odličnih - 73 ili 34,76\%,

- vrlo dobrih - 47 ili 22,38\%,

- dobrih - 41 ili 19,52\%,

- dovoljnih - 2 ili $0,96 \%$,

- nedovoljnih - 46 ili 21,90\%.

Škole su iste, a razredi nisu, jer je istraživanje u školskoj 1976/77. godini provedeno u VIII razredu, a 2015/16. u IX razredu jer je sada devetogodišnje osnovno obrazovanje i odgoj. S obzrom da se radi u oba slučaja o završnom razredu, smatramo da komparativno sagledavanje ima osnova i da se ostvareni rezultati mogu, uvjetno, uspoređivati. Vremenska distanca između ova dva ispitivanja je velika. Ne radi se o longitudinalnom niti o transferzalnom postupku u istraživanju pojava jer to objektivno nije ni moguće. Ali sagledavanje i kompariranje 
rezultata uvažavajući utjecaje vremenske distance i druge relevantne karakteristike odgojno-obrazovnih sistema pružaju mogućnost za izvođenje određenih zaključaka koji mogu biti od interesa kako za nauku tako i za unapređivanje odgojno-obrazovnog rada.

Najočitije razlike su u kategoriji odličnih učenika. U prvom slučaju je oko $13 \%$, a u drugom oko $35 \%$ ispitivanih. Ovdje treba pokušati utvrditi uzroke ovako velikoj razlici. Jesu li sadašnje generacije učenika mentalno zrelije, ambicioznije, sa boljim radnim navikama, ili su nastavnici promijenili kriterije u ocjenjivanju?

Posebno se to odnosi na kategoriju nedovoljnih učenika kojih je $\mathrm{u}$ prvom slučaju bilo oko $35 \%$, a u drugom oko $22 \%$. Sama spoznaja nije dovoljna. Komparativno sagledavanje i utvrđivanje uzroka uspjeha i neuspjeha, ne samo u osnovnim, nego i u srednjim školama na području USK-a zasigurno bi imalo pozitivne efekte za unapređivanje odgojnoobrazovnog rada.

U cilju unapređivanja sistema odgoja i obrazovanja, korisno bi bilo provesti temeljito istraživanje te sa pedagoškog, psihološkog, sociološkog i metodičkog aspekta pokušati doći do pravih odgovora kako o uspjehu tako i o opisnom ocjenjivanju u razrednoj nastavi kao i odgovora na druga pitanja. Istraživanje bi doprinijelo temeljitom i cjelovitom odgovoru o opravdanosti napuštanja opisnog ocjenjivanja u razrednoj nastavi koje je danas trend, posebno u I i II razredu osnovne škole, kako u zemljama našeg okruženja, tako i šire. Bez temeljitog istraživanja, svako rješenje je neutemeljeno i manjkavo.Zar ne bi bilo vrijedno utvrditi težinu torbaka, ruksaka učenika prvačića čija su leđa preuska i preslaba da ih nose. Skakuću za svojim roditeljima, nanama i djedovima, a i oni se nakrivili odupirući se težini ruksaka svojih unučića.

\section{Kraći osvrt na tok istraživanja}

Izbor škola i odjeljenja izvršen je hotimičnim uzorkom.

Pripremljeni su ZOT (zadaci objektivnog tipa) za provjeravanje učeničkih znanja i njihovih sposobnosti za učenje. Također su odabrani testovi za ispitivanje ličnosti s ciljem utvrđivanja faktora, osobina ili crta ličnosti koje imaju značajnijeg utjecaja na uspjeh u školskom učenju. Projektom istraživanja predviđeno je da se utvrdi nivo 
povezanosti između rezultata dobivenih primjenom ZOT, testova ličnosti, tj. sposobnosti, crta ličnosti i uspjeha u školskom učenju.

Pošlo se od osnovne hipoteze da uspjeh u školskom učenju zavisi od niza faktora i osobina ličnosti među kojima inteligencija zauzima primarno mjesto.

\section{Istraživačke metode}

U istraživanju su korištene slijedeće metode:

- Metoda proučavanja pedagoške dokumentacije;

- Metoda anketiranja;

- Metoda razgovora;

- Metoda testiranja;

- Metoda statističke obrade rezultata istraživanja.

\section{Mjerni instrumenti}

- ,PURDUE“ -neverbalni test za ispitivanje inteligencije;

- Katelov upitnik HSPQ za ispitivanje personalnih faktora;

- Aysenckov test ličnosti, EPI-forma, 14 PF za ispitivanje stepena ekstraverzije, introverzije i neuroticizma;

- ZOT za provjeravanje stepena usvojenosti obrađenih sadržaja.

\section{Opis mjernih instrumenata}

S obzirom na ograničenja obima članka, dat ćemo kratak opis najrelevantnijih mjernih instrumenata koji su korišteni u istraživanju.

\section{„PURDUE“, neverbalni test za ispitivanje inteligencije}

Autori testa su poznati psiholozi I. Tiffin, A. Gruber i Kay Inaba. Vrijeme rješavanja testa je 25 minuta.Test sadrži 48 zadataka koji su raspoređeni na dvije stranice po 24 zadatka. Na prvoj stranici testa nalazi se štampano uputstvo sa primjerima koji služe za uvježbavanje. Zadaci u testu slični su primjerima za uvježbavanje. Zadatak ispitanika 
je da iz nizova od 5 sličica, od koliko se i sastoji svaki zadataka, eliminira, prekriži onu koja ne spada u taj niz.

Ovaj test mjeri opću sposobnost i perceptivne sposobnosti.

\section{KATELOV test 14 PF za ispitivanje ličnosti}

Test je namijenjen za ispitivanje 14 faktora ličnosti koji sadrže niz osobina ili crta ličnosti. S obzirom da faktor označen sa oznakom „B“ mjeri inteligenciju ispitanika, podesan je za utvrđivanje stepena posjedovanja općih sposobnosti kod ispitanika. Uspjeh učenika u učenju tijesno je povezan sa personalističkim sklopom inteligencije našto ukazuje i G. Olport i ističe:“

Struktura inteligencije jedne ličnosti je idiografska, u osnovi jedinstvena, delimično zbog svog nikad ponovljenog nasleđa, a delimično stoga što je inteligencija nerazdvojno spojena sa celokupnom ličnošću. “22

\section{AJZENKOV TEST-EPI JUNIOR}

Test mjeri tri crte ličnosti:

- Ekstraverziju

- Introverziju

- Neuroticizam

Pored navedenih crta ličnosti ovaj test sadrži i pitanja koja ukazuju na lažne odgovore i čine skalu laži ili LAJ-skorove. Ispitanik koji je dao 5 i više odgovora koji su lažni, njegovi odgovori stavljaju se pod sumnju. Takav rezultat ili se isključuje iz obrade ili se vrši retestiranje kako bi se provjerilo da li su odgovori zaista lažni.

Uspjeh učenika u učenju tijesno je povezan sa personalističkim sklopom inteligencije našto ukazuje i G. Olport i ističe:"Struktura inteligencije jedne ličnosti je idiografska, u osnovi jedinstvena,

${ }^{22}$ Olport, G., Sklop i razvoj ličnosti, Kultura, Beograd, 1969, str. 91. 
delimično zbog svog nikad ponovljenog nasleđa, a delimično stoga što je inteligencija nerazdvojno spojena sa celokupnom ličnošću.“‘23

Treba istaći da uspjeh u učenju zavisi i od niza drugih faktora kao i od upornosti i predanosti učenju. Ispitivanja pokazuju da osobe sa prosječnim općim sposobnostima uz znatnije angažiranje i predanost postižu veoma zapažene rezultate. Zato R. Kvaščev ističe da je personalistički sklop inteligencije tijesno isprepleten $\mathrm{s}$ interesima, crtama ličnosti i pogledom na život što sve ima udjela u učenju i radu. Osim što postoje razlike među osobama u intelektualnim sposobnostima, razlike postoje i kod jedne te iste osobe s obzirom na situaciju i prirodu problema. Svaka osoba je prilagodljiva i savitljiva u određenim situacijama, dok je u drugim zavisnija od polja i kruta.

U formiranju ličnosti, njenih intelektualnih sposobnosti, temperamenta i osobina ličnosti, veliku ulogu igraju genetski/nasljedni faktori i utjecaji. Naslijeđe vrši univerzalni utjecaj na oblikovanje ličnosti i temperamenta. Svakako da tome treba dodati da je učenje poseban faktor koji igra važnu ulogu u uspjehu u svakoj djelatnosti. Zato R. Kvaščev, određujući pobliže personalistički sklop inteligencije kaže: "Ono što nazivamo personalističkim sklopom inteligencije jeste činjenica da je inteligencija isprepletena s interesima, crtama ličnosti, radoznalošću, osetljivošću za probleme, otvorenošću duha, sa bogatstvom i proizvođenjem ideja itd, i u tom smislu personalistički sklop inteligencije utiče na razvijanje određenog saznajnog stila kod ličnosti. “24

Ipak, ne smijemo zanemariti da postoje razlike među osobama sa sličnim intelektualnim sposobnostima. Tako jedna osoba, iako je inteligentna, zadatke rješava na konvencionalan način, konformista je, nesamostalna, sa slabo izraženim kreativno-istraživačkim stavom, druga osoba koja je u istoj mjeri inteligentna, rješavanju zadataka prilazi na originalan način, sa kreativno-istraživačkim stavom, samostalna je u radu i nije konformista. Znači da ove dvije osobe imaju različit personalistički sklop inteligencije i različit uspjeh u radu.

\footnotetext{
${ }^{23}$ Olport, G., Sklop i razvoj ličnosti, Kultura, Beograd, 1969, str.91.

${ }^{24}$ Kvaščev, R., Podsticanje i sputavanje stvaralačkog ponašanja ličnosti, IP Svjetlos, Sarajevo, 1975.
} 
Inteligencija, temperament i tjelesna građa predstavljaju sirovi materijal iz koga se oblikuje ličnost. Ličnost je dosta zamršena i komplicirana psihička struktura i vrlo teško je ispitati i spoznati. Individualnost je osnovna karakteristika ljudske prirode i zato psiholozi ističu za svaku ličnost da je:

- kao svi drugi ljudi,

- kao neki drugi ljudi,

- kao ni jedan drugi čovjek.

Dakle, ličnost je univerzalna pojava iako se nalazi samo u individualnim oblicima. Socio-kulturni sistem značajno utječe na ličnost i njeno formiranje.

Pored svega navedenog, ne treba zaboraviti na veliku ulogu i značaj motivacije za učenje i ostvarivanje visokih rezultata. Primarna, intrinzična ili unutrašnja motivacija, kao i sekundarna, ekstrinzična ili vanjska motivacija podstiču, održavaju, energiziraju aktivnost učenika i tako doprinose uspjehu. Ovdje valja istaći značaj i ulogu motivacionog ciklusa ponašanja, prisutnog kod svake osobe. On započinje postojanjem motiva za određenu aktivnost. Ali samo postojanje motiva nije dovoljno. Potrebno je da uslijede određena ponašanja koja se označavaju kao instrumentalna ponašanja osobe. Dakle, neophodno je iznalaziti instrumente i postupke koji će potpomagati zadovoljenje motiva. To neminovno uslovljava niz radnji i akivnosti kako bi se savladale/prepreke, barijere na koje osoba nailazi. Savladavanjem prepreka/barijera osoba ostvaruje zacrtani cilj, dakle, zadovoljava motiv. Ali to nije kraj, jer se odmah javlja novi motiv kojeg osoba želi da zadovolji. Slijedi postupak koji je već opisan i tako redom do ostvarivanja krajnje zacrtanog cilja. S obzirom da je ovo proces koji traje tokom života, svaka osoba nastoji da ostvari svoj motiv samoaktualizacije ili samopotvrđivanja, a to je zamišljeni daleki cilj kojeg osoba može ostvariti u skladu sa svojim sposobnostima, mogućnostima, potencijalima. Međutim, mnoge osobe ne ostvare svoju samoaktualizaciju tokom života. Samo najupornije, najambiciozniji s visokim intelektualnim potencijalima, $s$ jakom primarnom i sekundarnom motivacijom, upornim radom i nastojanjem, trudom i zalaganjem dostižu do nivoa vlastite samoaktualizacije. 


\section{Korelacija između inteligencije i personalnih faktora ličnosti}

Povezanost ili korelacija između opće inteligencije i određenih faktora ličnosti sadržanih u Katelovom upitniku HSPQ-14 PF, a utvrđenih istraživanjem na opisanom uzorku ispitanika, je pozitivna i statistički značajna. To se posebno odnosi na korelaciju između opće inteligencije i osobina ličnosti kao: srdačnost, prilagodljivost, velikodušnost, emocionalna zrelost i stabilnost, uzbudljivost, nestrpljivost, zainteresiranost, agresivnost, dominantnost i submisivnost, pouzdanost i samouvjerenost. 25

Pozitivna korelacija utvrđena je i između inteligencije i osobina kao što su: iskren, impulsivan, lider, entuzijasta, bezbrižan, druželjubiv kao i osjećajnosti, pažljivosti prema drugima, samodiscipliniranosti, visoke samokontrole, prisebnosti, napetosti, poduzetosti, razdražljivosti. Veliki broj osobina koje čine sadržinu personalističkog sklopa faktora, statistički su značajno povezani sa inteligencijom što se dovodi u vezu sa učenjem. Među ostalim to su: prihvatanje i izvršavanje obaveza, osjećaj odgovornosti, savjesnost $\mathrm{i}$ istrajnost $\mathrm{u}$ radu, obzirnost prema drugima, zainteresiranost, samouvjerenost, pozitivna slika o sebi i niz drugih, a sve su integrirane u jednu jedinstvenu cjelinu i svojom povezanošću sa inteligencijom doprinose da se uspješno ili manje uspješno obavljaju različite djelatnosti.

Sve navedene osobine i mnoge koje nisu iz opravdanih razloga spomenute čine jednu organizovanu, integriranu i jedinstvenu cjelinu $i$ sadržane su u personalističkom sklopu koje zajedno sa inteligencijom učestvuju i doprinose uspješnom učenju. Intelektualne sposobnosti, fizička i psihička konstitucija čine osnovu koja uz povoljnu porodičnu atmosferu, socijalnu osjetljivost, emocionalnu stabilnost i niz pozitivnih osobina ličnosti obezbjeđuju uspjeh u životu i radu. Njivovo poznavanje ima veliki značaj i za uspjeh osoba s teškoćama u razvoju. Uvažavanje personalističkog sklopa inteligencije pruža garanciju ispravno odabranog načina rada i s djecom s teškoćama u razvoju uz puno uvažavanje individualnih razlika i posebnih potreba svih sudionika odgojno-obrazovnog rada.

25 Ramić, O., Utjecaj personalističkog sklopa inteligencije na uspjeh učenika $u$ školskom učenju, (Magistarski rad, Filozofski fakultet Univerziteta u Sarajevu, Odsjek za pedagogiju i psihologiju, Sarajevo, 1976. 


\section{Emocionalna zrelost i uspjeh u učenju}

Provedenim istraživanjima utvrđeno je da postoji statistički značajna povezanost između emocionalne zrelosti, inteligencije i sposobnosti za učenje. S obzirom na velike razlike među subjektima u njihovoj personalističkoj strukturi ličnosti, njihova emocionalna zrelost proteže se od pubertetske pa do vrlo dobre. Od 171 ispitanika ni jedan nije na nivou infantilne emocionalne zrelosti, a samo jedan učenik je pokazao dječiju emocionalnu zrelost, Ali nema ni jednog učenika sa potpunom emocionalnom zrelošću.

Ispitanici su se rasporedili prema slijedećim kategorijama:

- infantilna emocionalna zrelost------------------ 0 - 9 bodova, ni jedan ispitanik;

- dječija emocionalna zrelost----------------------10 - 12 bodova, jedan ispitanik;

- pubertetska emocionalna zrelost----------------13-16 bodova, 20 ispitanika;

- prosječna emocionalna zrelost--------------------17-20 bodova, 88 ispitanika;

- vrlo dobra emocionalna zrelost-------------------21-24 boda, 62 ispitanika,

- potpuna emocionalna zrelost---------------------25 bodova, ni jedan ispitanik.

Prema pokazateljima, ispitanici koji su pokazali da posjeduju vrlo dobru emocionalnu zrelost su, uglavnom, odlični i vrlo dobri učenici po općem uspjehu u učenju. Učenici sa pubertetskom i dječijom emocionalnom zrelošću su pretežno sa slabijim općim uspjehom. Stabilna i vrlo dobra emocionalna zrelost imala je za rezultat bolja postignuća u učenju. Ove osobe drugačije osjećaju život, aktivnije su i nastoje da istinski učestvuju u značajnim oblastima ljudskog rada. To ukazuje na činjenicu da i emocionalna zrelost kao dimenzija ličnosti je veoma postojana osobina $\mathrm{i}$ da učestvuje u personalističkom sklopu sveukupnih intelektualnih sposobnosti te ima značajnog udjela $u$ uspješnom učenju. To potvrđuje i mišljenje Danijela Golemana, poznatog američkog psihologa, koji se posebno bavio proučavanjem 
emocionalne inteligencije i došao do spoznaje da je emocionalna inteligencija u mnogim zanimanjima ravnopravna pa čak i značajnija od akademske inteligencije

Za uspješno učenje i uopće napredovanje značajnu ulogu imaju dimenzije ličnosti koje se manifestuju kroz ekstraverziju, introverziju i neuroticizam. Engleski psiholog Hans Ajzenk ističe da svaka individua posjeduje neki stepen svake od navedenih dimenzija. To znači da je svaka osoba u izvjesnoj mjeri $u$ isto vrijeme i ekstravertna $\mathrm{i}$ introvertna $\mathrm{i}$ da posjeduje izvjestan stepen neurotičnosti. Prema Ajzenku, u rješavanju testova inteligencije ekstravertne osobe se odlučuju za brzinu zbog čega prave lako greške. Introvertne osobe se opredjeljuju za sporije rješavanje zadanih zadataka, rade $\mathrm{s}$ više strpljenja, racionalnije koriste raspoloživo vrijeme i prave znatno manje grešaka. I naše istraživanje je pokazalo da postoji razlika u stepenu povezanosti između inteligencije i ovih dimenzija ličnosti.

Neurotičnost kao dimenzija ličnosti u manjoj ili većoj mjeri prisutna je kod svake osobe. Negativno se odražava na intelektualne sposobnosti i na sposobnost za učenje. Ajzenk neurotičnost definiše kao lošu organizaciju ličnosti, abnormalan strah od bolesti, prisutnosti slabe energije, vrlo ograničeni interesi i emocionalna nestabilnost. Kod osoba kod kojih je neuroticizam jače izražen pokazuju strah od neuspjeha $\mathrm{u}$ učenju, nemaju povjerenja u vlastite sposobnosti i mogućnosti, nemaju hrabrosti da izraze svoje mišljenje i stavove. Kad je riječ o učenicima, odgajatelji imaju veliku odgovornost da prepoznaju takve učenike i da im pruže pomoć i podršku. Pravovremena pomoć odgajatelja može biti od presudnog značaja za budućnost takvih učenika.

\section{ZAKLJUČAK}

\section{Ovim radom željeli smo ukazati}

Struktura inteligencije i njenog personalističkog sklopa kod ličnosti je idiografska (svoja,vlastita), u osnovi jedinstvena, nikad ponovljiva i nerazdvojno spojena sa cjelokupnom ličnošću. Personalistički sklop inteligencije svake ličnosti isprepleten je interesima, mnogobrojnim crtama ili osobinama ličnosti i pogledom na život. Mnogobrojne crte ili osobine ličnosti svojim ispreplitanjem il kombinovanjem, omogućavaju veliki broj novih osobina i njihovih kombinacija. Upravo zato, različit 
personalistički sklop inteligencije ima i različit utjecaj na uspjeh učenika u školskom učenju. Dakle, svaka ličnost posjeduje svoj personalni identitet.

Za ostvarivanje dobrog uspjeha značajno je da učenici imaju razvijene sposobnosti za učenje, da su savladali tehniku učenja i da imaju motivaciju za učenje. Preopterećenost i neizdiferenciranost nastavnih programa nastavnih predmeta čine nastavne predmete teškim i kod značajnog broja učenika stvara se odbojan stav prema učenju pa i školi.

Važna komponenta personalističkog sklopa inteligencije je, pored ostalih, i emocionalna zrelost koja može varirati od infantilne do potpune emocionalne zrelosti. S pravom se očekuje da se učnici, zavisno od uzrasta, znaju društveno prihvatljivo ponašati, da su uravnoteženi i da znaju kontrolisati svoje emocionalno stanje. Istraživanjem smo utvrdili da postoji statistički značajna korelacija emocionalne zrelosti i opće inteligencije i da ona iznosi $\mathrm{r}=0,74(\mathrm{t}=14,3)$.

Istraživanjem je ustanovljeno da na uspješno učenje značajno djeluje motiviranost učenika za učenje i jasno postavljeni bliži i dalji ciljevi. U odgojno-obrazovnom radu odgajateljitrebaju svakodnevno podsticati primarnu, unutrašnju, intrinzičnu i sekundarnu, vanjsku, ekstrinzičnu motivaciju i tako učenike čvrsto vezati za nastavne predmete $\mathrm{i}$ programske sadržaje koje predaju. Redovitim praćenjem napredovanja, svakodnevnim podsticanjem i nagrađivanjem, ukazivanjem na načine uspješnog učenja, kontinuiranim povratnim informacijama o rezultatima rada možemo kod učenika povećavati njihove kompentencije.

Svaka osoba u određenoj mjeri manifestira ekstravertnost, introvertnost, neurotičnost.

Dominacija neke od ovih dimenzija doprinose ili otežavaju uspješno učenje. H. Ajzenk je utvrdio da ekstraverti u rješavanju testova inteligencije pokazuju izvjesnu nestrpljivost, žure i zato mnogo griješe, dok introverti su skloniji staloženosti, usporenijem rješavanju zadataka i čine znatno manje grešaka. Zavisno od stepena izraženosti, neurotičnost se negativno odražava na uspješno rješavanje zadataka pa i svakodnevnih problema. Često je pomoć najpotrebnija onima koji je najmanje zaslužuju, ali odgajatelj mora smoći snage da ,pobijedi“. To 
je specifičnost, težina ali i ljepota našeg poziva i dužni smo ostati njemu dosljedni.

Pozitivna i statistički značajna povezanost utvrđena je između inteligencije i osobina ličnosti kao: iskren, impulsivan, lider,entuzijasta, bezbrižan, druželjubiv, kao i osjećajnosti, pažljivosti prema drugima, samodiscipliniranosti, prisebnosti, poduzetnosti. Među osobinama koje čine sadržinu personalističkog sklopa inteligencije, povezane su sa inteligencijom i značajno utječu na uspješno učenje su: prihvatanje i izvršavanje obaveza, osjećaja odgovornosti, savjesnosti i istranosti u radu, obzirnosti prema drugima, zainteresiranosti, samouvjerenosti, s pozitivnom slikom o sebi i sl. Sve spomenute i one koje iz ograničavajućih razloga nisu spomenute integrirane su u jednu jedinstvenu cjelinu i zajedno sa inteligencijom čine personalistički sklop koji igra odlučujuću ulogu u uspješnom učenju i uopće djelovanju. Njihovo poznavanje ima značajnu ulogu i za osobe s teškoćama u razvoju kao i za sve osobe s posebnim potrebama bez obzira na njihov uzrok.

Dakle, personalistički sklop inteligencije ima dalekosežan značaj za uspješan rad, učenje i djelovanje te je njegovo poznavanje višestruko značajno i korisno.

Ovim radom željeli smo ukazati na postojanje očitih razlika $u$ ostvarenim rezultatima učenika u učenju na kraju I polugodišta školske 1976/77. godine i školske 2015/16. godine. Ideja je da se u narednom periodu provede sveobuhvatnije istraživanje ostvarenih rezultata učenika završnog razreda devetogodišnje osnovne škole. Dobiveni rezultati mogli bi poslužiti za dokazivanje opravdanosti i egzistiranja devetogodišnjeg odgoja i obrazovanja i eventualnog preispitivanja opravdanosti ukidanja opisnog ocjenjivanja u II i III razredu devetogodišnje osnovne škole. 


\section{Literatura}

1. Berk, E. Laura, Psihologija cjeloživotnog razvoja, Naklada Slap, Jastrebarsko, 2008.

2. Furlan, Ivan, Osnove procesa učenja, Zagreb, Školska knjiga,1969.

3. Ingliš, Horas i Ingliš, Eva, Obuhvatni rečnik psiholoških $i$ psihoanalitičkih pojmova, Savremena administracija, Beograd, 1972.

4. Katel, Rejmond, Naučna analiza ličnosti, Beogradski izdavačkografički zavod, Beograd, 1978.

5. Kvaščev, Radivoj, Primena teorija učenja na oblast nastave $i$ vaspitanja, Beograd, Zavod za izdavanje udžbenika SR Srbije, Beograd,1967.

6. Olport, Gordon, Sklop i razvoj ličnosti, Kultura, Beograd, 1969.

7. Rathus, S.A, Temelji psihologije, Naklada Slap, Jastrebarsko, 2001.

8. Ramić, Osman, Sposobnosti i oosobine ličnosti invalida rata u funkciji edukacije i zapošljavanja, Grafičar, Bihać, 2006.

9. Ramić, Osman, Utjecaj karaktera učenika na školski uspjeh $i$ ponašanje, Pedagoški fakultet Univerziteta u Bihaću, Bihać, 2011.

10. Sternberg, R.J. Kognitivna psihologija, Naklada Slap, Jastrebarsko, 2005.

11. Vasta R., Haith M.M., Miller S. Dječija psihologija, Naklada Slap, Jastrebarsko, 1998.

12. Vizek-Vidović, V., Vlahović-Štetić, V., Rijavec, M., Miljković, D. Psihologija obrazovanja, IEP Vern, Zagreb, 2003.

\section{Ostali izvori}

1. Makić, Adil, Komparacijaodgoja i obrazovanja u islamskoj $i$ konvencionalnoj pedagogiji (neobjavljeni magistarski rad), Islamski pedagoški fakultet Univerziteta u Bihaću, Bihać, 2015.

2. Ramić, Osman, Uticaj personalističkog sklopa inteligencije na uspjeh učenika u školskom učenju (neobjavljeni diplomski rad), Filozofski fakultet Univerziteta u Sarajevu, Odsjek za pedagogiju i psihologiju, Sarajevo, 1976. 
Osman Ramic, PhD

\section{PERSONALISTIC COMPONENTS OF INTELIGENCE AND SUCCESSFUL LEARNING}

\section{Abstract}

Since learning is a central concept when it comes to education, it is necessary to devote full attention to it. It is the duty of schools to train pupils for independent learning and to develop competences that enable them to be active participants in the teaching process. By taking into account individual abilities of each pupil, teachers will create a socio-emotional climate in the classroom that will ensure equal treatment and successful mastering of educational material by all pupils, according to their abilities and skills. The responsibility of teachers is big, hard, but also noble and beautiful. Is there anything more beautiful than relationship between teachers and students?

Current issue in today's school is the inclusion of children with disabilities into regular classes. This is a very important moment in the system of education because it is related to people who have special needs in terms of disability and inevitably require special treatment in order to achieve results in accordance with their capabilities and abilities. Therefore, it is very important to know the personal components of intelligence of each student. This knowledge directs us how to successfully work, how to harmonize our requirements, and which methods and procedures to apply in order to achieve optimal results with pupils.

Successful learning will be achieved by those educators who manifest love interest and expertise in the work they do. However, this is only one side of a successful educational work. The participants in the teaching process are (or at least should be) pupils whose success in learning depends on their efforts. Their interest, motivation to learn with the proper use of their own resources will ensure that learning is successful.

Keywords: personal components, intelligence, learning, extraversion, introversion, neurosis, social maturity, emotional maturity, factors, G-factor, intrapersonal sensitivity, interpersonal sensitivity, artificial/manmade/computer intelligence, intrinsic motivation, extrinsic motivation. 


\section{الأستاذ الدكتور عثمان راميتش'}

\section{التشكيلة الشخصية للذكاء والدراسة الناجحة}

\section{الخلاصية}

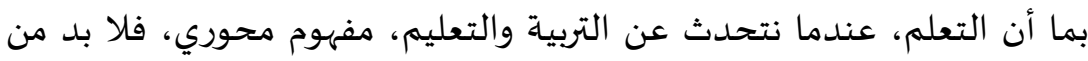
إعطائه الاهتمام الكامل. واجب المدرسة أن تؤهل التلاميذ للتعلم المستقل وأن تنميّ فيهم التهيه الكفاءات تمكّنهم من لعب دور فاعل في العملية التعليمية. من خلال مراعاة القدرات

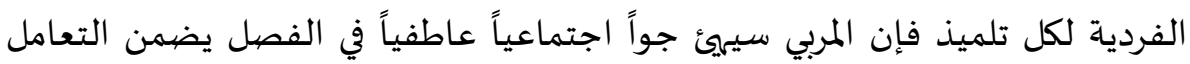

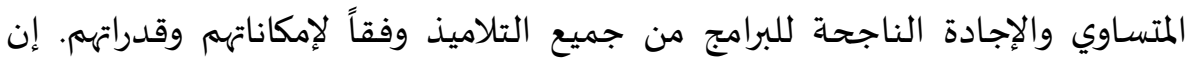

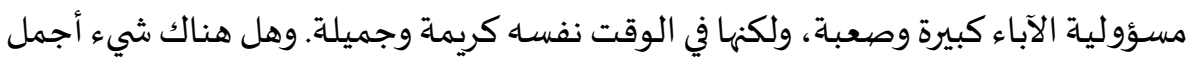

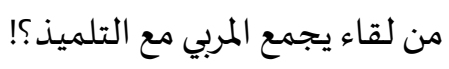
المسألة الآنية في المدرسة اليوم هي دمج الأولاد ذوي الإعاقة في الفصول النظامية وهي

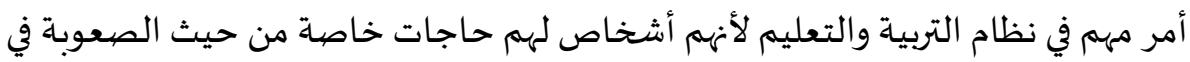
النمو ولا شك أنهم يتطلبون معاملة خاصة لتحقيق النتائج وفقاً لإمكاناتهم وقدراتههم. لذا ماتها من المهم معرفة التشكيلة الشخصية للذكاء لدى كل تلميذ. تلك المعرفة توجّهنا كيف لته

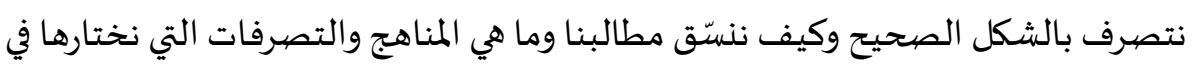

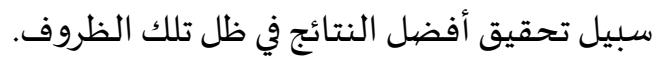
التعليم الناحج سيحقّقه المربون الذين يظهرون في عملهم الحب والاهتمام والاحترافية للعمل الذي يمارسونه. ولكن هذا جانب واحد من جوانب التعليم والتربية

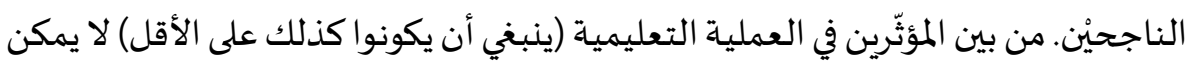

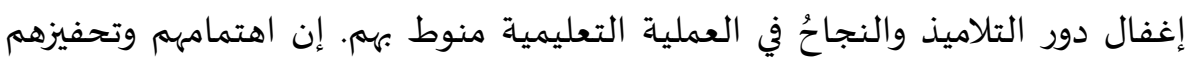

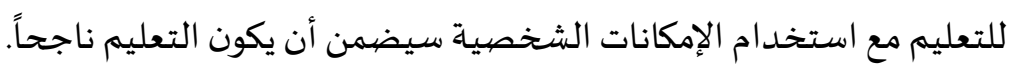

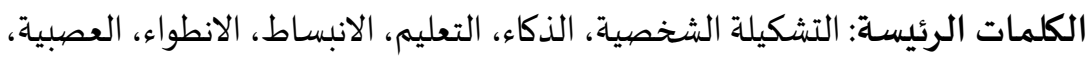

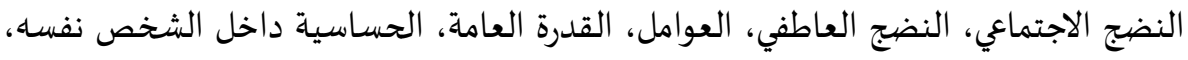

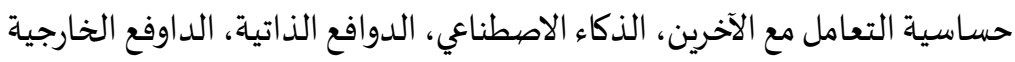

